Alicja Kisielewska

University of Biatystok

\title{
Crime and Punishment: The Selected Tenets of the Decalogue in the Polish Television Series Ojciec Mateusz [Fr. Matthew]
}

This article considers whether the popular Polish drama-crime television series Ojciec Mateusz [Father Matthew], which is directed by Maciej Dejczer and has been broadcast on TVP1 since 2008, prompts viewers to reflect on Christian moral norms. This research includes the fields of cultural studies and moral theology. From the point of view of moral theology, the theme of Ojciec Mateusz is the battle between good and evil, the basis of which is the tenets of the Decalogue. This study attempts to answer the questions: Is the religiosity hidden in this series, which does not assume the religiosity of the series' viewers, evoke religious sentiments among those who believe? And, does the series affect the moral formation of those who do not believe?

Key words: Decalogue, television series, moral theology.

\section{Introduction}

This article considers whether the popular Polish drama-crime television series Ojciec Mateusz [Father Matthew], which is directed by Maciej Dejczer and has been broadcast on TVP1 since 2008, prompts viewers to reflect on Christian moral norms. This series is the Polish version of the Italian series Don Matteo, which has been broadcast on the public television station Rai Uno since 2000. In Ojciec Mateusz, the main character is the Catholic priest Fr. Matthew Żmigrodzki (played by Artur Żmijewski), who, after years on the mission field of Belarus, returns to Poland and becomes the pastor of a small parish on the outskirts of Sandomierz. In addition to caring for his parish and ministering to his people, Fr. Matthew has a talent as a detective 
Theology of Culture

and helps the local police solve the most difficult criminal cases. Fr. Matthew's collaboration is made possible through his friendship with the local policeman and aspirant, Mieczysław Nocul, who reveals the details of his investigations to Fr. Matthew. ${ }^{1}$

The priest is the main character of the series, and, as someone associated with the institutional Church, he not only determines the religious aspects of the series, but also is a characteristic element of a religious film. According to the genre of religious film, three types of works can be categorized as religious: film adaptations of the Bible, hagiographic films, and stories about the lives of clergy and religious. When understood more broadly, religious films can also include works that explore the search for the meaning of existence. ${ }^{2}$ Tomasz Kłys includes outstanding artistic cinema among religious films, since these works express the religiosity of their authors or metaphysical questions related to the search for truth. Kłys also proposes that "paradoxically religious" works can be analyzed as religious films, even though they do not belong in this category, because they evoke "experiences and reflections of a religious nature" ${ }^{3}$ in the viewer. I would add to this group "paradoxically religious" television series whose protagonists are priests, religious, or others who incline viewers to entertain reflections of a religious nature. One such series is Ojciec Mateusz, since it presents simplified pop-cultural considerations on the main tenets of the Decalogue. This raises the question: Does the series' hidden religiosity, which does not necessarily imply that the viewers are pious themselves, arouse religious sentiments in viewers who believe and influence the moral formation of both believers and unbelievers alike? It is important to note that the characters in the series frequently express their religious indifference directly. However, the fact that the protagonist is a priest may provoke in viewers a desire to explore transcendent realms or, more broadly, spirituality.

Cultural studies and moral theology are the points of view from which this reflection will take place. From the perspective of cultural studies, Ojciec Mateusz is a popcultural text produced by the television industry in Poland. After the cultural transformation that took place in Poland, when it was officially possible to speak about people in the

\footnotetext{
1 The series is filmed primarily in Sandomierz, which is reminiscent of Gubbio, a city in central Italy where the series Don Matteo takes place.

$2 \quad$ M. Kempna, "Religijność jako paratekst. Na obrzeżach teorii filmu religijnego," in Pogranicza audiowizualności. Parateksty kina, telewizji i nowych mediów, ed. A. Gwóźdź (Kraków: 2010), 243-244.

3 T.Kłys, "Filmy (nie)religijne," in Między stowem a obrazem, eds. M. Jakubowska, T. Kłys, and B. Stolarska (Kraków: 2005), 186.
} 
Church, several television series with Catholic priest protagonists were produced, including: Plebania [The Rectory] (2000-2011), Ranczo [The Ranch] (2006-2009; 2011-2016), as well as series where priests played supporting roles, including: Blondynka [Blondie] (2010; 2013-), Korona królów [The Kings' Crown] (2018-), M jak miłość [L as in 'Love"] (2000-), and Złotopolscy (1998-2010). All of these productions depict priests stereotypically and rather sympathetically. In Ojciec Mateusz, the priest Fr. Matthew and other priests, including the archbishop, are presented positively and humorously. They play an essential role in the life of the community in which they are readily involved. The manner in which the character Fr. Matthew is presented in Ojciec Mateusz follows the same scheme and format of the Italian series Don Matteo but is adapted to Polish culture. In addition, Ojciec Mateusz is broadcast on public television; therefore, the series has a kind of missionary element and social purpose. Above all, however, the series is entertainment that should be attractive in order to reach the widest audience possible. ${ }^{4}$ The characters and locations in which the show is filmed serve this end. The series takes place in the police station and parish rectory, which serves as a second "command center" where Fr. Matthew solves crimes often over tea or a game of chess while the people who gather around the priest's housekeeper form an extended family. Not only those who love crime novels but also families can enjoy the series. ${ }^{5}$ The visual attractiveness is another important element that draws in viewers. For example, the image of Fr. Matthew in a cassock blowing in the wind as he rides his bicycle through the town square of Sandomierz is charming. The pop-cultural image of a Catholic priest who rides a bike, plays chess, has a talent for solving crimes, and hurries to the aid of every person in need is far from the typical image of a priest celebrating Mass at the altar. Although the elements of the character of Fr. Matthew are drawn from the world of pop culture and secular reality, he is also a consecrated person and,

4 To this end, the series uses a variety of marketing strategies: product placement (e.g., Inka coffee), city placement (e.g., the plot of Ojciec Mateusz takes place in Sandiomierz which encourages set-jetting, or the trend of visiting destinations seen in television series or movies). See https://depot.ceon.pl/ handle/123456789/16620, accessed May 1, 2021.

5 The series is popular and had approximately 2.13 million viewers as of autumn 2020. See Michał Kurdupski, "2,13 mln widzów Ojca Mateusza w nowym paśmie, TVP1 liderem," Wirtualnemedia, accessed May 1, 2021, https://www.wirtualnemedia.pl/artykul/ogladalnosc-ojciec-mateusz-serial-ma2-13-mln-widzow. 
Theology of Culture

therefore, a hero of religious cinema who, for both his creators and the viewers, is a "natural indicator of Christian spirituality." 6

From the point of view of moral theology, the main theme of Ojciec Mateusz is the battle between good and evil, which is based on the tenets of the Decalogue. According to Christian doctrine, the Decalogue is the Ten Commandments that God gave to Moses on Mount Sinai. These commandments set forth the principles by which societies should live. ${ }^{7}$ At the same time, the Ten Commandments are not only a set of "shall" and "shall nots," but also incentives to live happily in communion with God and man. "The clear direct, and unconditional 'thou shall' and 'thou shall not' distinguish the Decalogue from all other biblical casuistic law, which is conditional." In the New Testament sense, the Decalogue is the moral law that God gave to man for man's own good. ${ }^{10}$ "According to Karol Wojtyła, the [Decalogue] is the foundation of later Christian morality."

In the series Ojciec Mateusz, the main character, Fr. Matthew, establishes the Christian moral system, particularly the Ten Commandments which prohibit certain acts, as the reference point. The "shall nots" refer to the fifth through the tenth Commandments that define the moral obligations that people have toward each other and toward that which belongs to each person. ${ }^{12}$ According to moral theology, which "formulates norms based on the truths of the faith,"13 the moral

$6 \quad$ M. Marczak, "Postać filmowa jako nośnik religijnego znaczenia. Ekranowe obrazy osób konsekrowanych w polskim kinie i telewizji od 2000 roku w funkcji socjokulturowego przekazu na temat współczesnej religijności," Media - Kultura - Komunikacja Społeczna 2, no. 12 (2016): 50.

Ibid, 65 .

W. Harrelson, "Dziesięcioro Przykazań," in Słownik wiedzy biblijnej, eds. B. Metzger and M. Coogan, (Warszawa: 1996), 135-136.

F. Rienecker and G. Maier, eds., "Dziesięcioro przykazań,” in Leksykon biblijny, trans. D. Irmińska (Warszawa: 2008), 192.

SeeA.Kraska, "Wj20,13-14.16.12," Wymiartranscendencji Dekalogu Krzysztofa Kieślowskiego wobec dylematów wspótczesnego człowieka (doctoral dissertation, Adam Mickiewicz University, Department of Theology, 2017), 18, accessed May 1, 2020, https://repozytorium.amu.edu.pl/handle/10593/20687.

Ibid, 20.

"You shall not kill. You shall not commit adultery. You shall not steal. You shall not bear false witness against your neighbor. You shall not covet your neighbor's house. You shall not covet your neighbor's wife, his male or female slave, his ox or donkey, or anything that belongs to your neighbor" (Ex 20:13-17).

O. C. J. Wichrowicz, Zarys teologii moralnej w ujęciu tomistycznym (Warszawa: 2016), 9. 
good, which motivates the characters' actions, is essential. Fr. Matthew and other characters personify the good, while the different criminals in each episode personify evil. The virtue of social justice, which Fr. Matthew embodies, plays a special role in the plot. According Cyprian Wichrowicz, social justice "directs human life to the common good and often makes it perceptive to different social issues." ${ }^{14}$ Ideological oppositions to the virtues presented in the series are "flaws" arising from the morally evil actions of certain characters. In the series, the most common opposition to the virtue of justice occurs through: murder, theft, fraud, and slander. ${ }^{15}$ Since the twenty-fifth season of Ojciec Mateusz is currently being aired, and since each episode within the series is a contained whole, this article will focus on analyzing a selection of episodes in order to substantiate the thesis.

Fr. Matthew is a very good priest and spiritual guide to his faithful. Many people would like to have such a parish priest. As both a priest and a person he is good, prudent, and just. Justice is of particular value because it is connected with social order and the proper relationship between people. "Many commandments pertain to justice, which indicates that [justice] is a deontological value, meaning that the individual should be just and act justly (it is a moral doctrine). This pertains the Decalogue in particular, since the entirety of it concerns justice. [The Decalogue] demonstrates how natural law regulates how people should relate to each other." ${ }^{\text {"16 }}$ It is important that the main character follows the principle of justice and demonstrate how one should behave in specific situations, i.e., how to live out the moral good. In the first episode of the series, when the plot is being laid out, the main moral directives that guide Fr. Matthew's decision and actions are also set forth. During the first Mass that he celebrates in his parish church, Fr. Matthew says to the faithful: "Clearly God wanted me to celebrate this Holy Mass with you and for us to seek the Lord together. I am here to serve you, but I also want you to treat me as a friend and brother to whom you can always come with your problems and your concerns, so that we can solve your problems together." 17 The first opportunity to serve appears just after Mass when a woman dressed in black approaches Fr. Matthew and asks him to celebrate the funeral Mass for her husband who supposedly committed suicide (although the wife does not believe that he did). As a result of his own investigation,

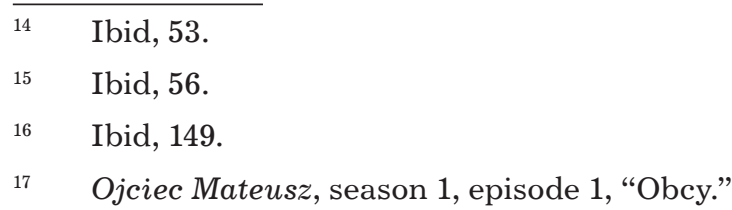


Fr. Matthew discovers that the man's death was an accident that was covered up initially by claims that he committed suicide and then that he was murdered. In the process, Fr. Matthew comes to the aid of Azer, an Armenian who works in the paper mill and was falsely accused of murdering the woman's husband. The person guilty of the accident-or, rather, murder - turns out to be the owner of the paper mill who tried to save money by evading implementing safe working conditions for his employees. The police detained the perpetrator who felt no remorse for his actions. Fr. Matthew celebrated the funeral mass, which was an occasion to share deeper moral reflections. In his homily, he spoke about prosperity that led to indolence. He also presented the Christian hierarchy of values, according to which: “...it is not important what is on the outside of a person [what he wears], but rather what is within him." He also spoke about how the conscience reproaches a person even when it is dormant, which becomes unbearable; "it is hell—the hell of rebuff." 18

Subsequent seasons of the series show the consequences of rejecting the tenets of the Decalogue. Questions concerning the reasons why people violate moral norms usually arise in the background of the crime stories. In Ojciec Mateusz, it is customary for people who are lost in some way to commit the crimes. In every episode there is a battle between good and evil, which-in a sense-Fr. Matthew animates. The most important element, however, is that good prevails and evil is punished through the execution of justice and by Fr. Matthew and other characters' moral judgment. In the series, narration takes place through dialogue; the characters often discuss events, which is part of the conventions of this genre. In this regard, Fr. Matthew's different commentaries are particularly important. The most common violation of the Ten Commandments takes place through sins against the virtue of justice.

\section{You Shall Not Kill}

In the series, evil is part of banal everyday life and occurs in beautiful surroundings that are both characteristic of the genre and a general indication of the culture. Most often, evil takes place in the form of a serious crime, i.e., murder. The criminals in the series are seemingly ordinary people. It is very rare for habitual offenders to appear in Ojciec Mateusz. The criminal stories presented in the series contain a hidden religious message. Every episode follows the same characteristic

$18 \quad$ Ibid. 
scheme: a crime is committed; an investigation is conducted; and the perpetrator is found. Fr. Matthew then speaks with the perpetrator, who is persuaded to admit his or her guilt. While these conversations prompt moral reflection and are an essential element of the series, the primary mode of reflection that takes place onscreen is through Fr. Matthew's witness, which serves as a reminder that a transcendent reality, the center of which is God, exists. ${ }^{19}$ In his witness, the viewer sees vocation as serving others in the name of charity, of which God is the source.

Murder is the topic of many episodes of Ojciec Mateusz-murder committed for two different reasons. In the first instance, the characters commit murder in order to gain some sort of profit from it. The victims are wealthy people. For example, lawyer of Polish descent who lives in Germany blackmails and then murders Mr. Borowski, a businessman who lived in a luxurious mansion. ${ }^{20}$ In another episode, a desire for money also drives a young man and con artist to trick older wealthy women into killing the owner of the florist shop. ${ }^{21} \mathrm{In}$ yet another episode, the owner of an art gallery to murders a security guard in order to obtain a large payment from insurance. ${ }^{22}$ Another interesting example is an episode where the action takes place in a house that an elderly woman left to the Archbishop of Sandomierz's curia. The house had formerly been a social agency. The owner of the agency had killed one of his female workers-a Ukrainian woman who recorded and then blackmailed customers. ${ }^{23}$ The home later became a center for the autistic, and another Ukrainian woman-a friend of the murdered woman-who was a pedagogue by education, worked there. This episode demonstrated how a moral good can arise from the darkness of a crime. In a different instance where greed is the motive and the criminals are not remorseful, Fr. Matthew offers no consoling words; instead, the murders are found and imprisoned. In a legal sense, punishment is meted out, and in a moral sense, Fr. Matthew sometimes makes a judgment or the viewers are left to make their own judgment.

The situation differs when people commit murder but unintentionally. For example, in one episode a former dancer, who sewed costumes for artists after suffering an injury years earlier, murdered another dancer. The murdered dancer owed the costume designer a large sum

\footnotetext{
$19 \quad$ M. Marczak, "Postać filmowa," 50.

$20 \quad$ Ojciec Mateusz, season 16, episode 210, "Reggae."

$21 \quad$ Ojciec Mateusz, season 16, episode 212, "Wahadełko."

22 Ojciec Mateusz, season 25, episode 321, "Woda sodowa."

23 Ojciec Mateusz, season 25, episode 320, "Spadek"
} 
of money that the designer had planned to use to pay for an operation. When the designer asked the dancer to repay the loan, he began to deride her, and she stabbed him with scissors. As the designer told Fr. Matthew, she only wanted to hurt the man, not kill him. The priest spoke with the woman for a long time, after which she admitted her fault and expressed remorse for what she had done. ${ }^{24}$ At the end of the episode, Fr. Matthew stated that, because the man had died, the woman would have make atonement. But he also added that God forgives a person when He sees that the person is truly contrite. In a morally similar episode, a mentally ill man commits murder out of love. The man kills Ewa Wiślicka, the wife of a rich businessman and the man's former girlfriend. ${ }^{25}$ It was left up to the viewers to judge the act.

A priest solving crimes can serve as an opportunity to bring up modern man's moral principles. In the series, the moral dilemmas that characters face are connected with many important and different social issues. For example, one episode touches on the in vitro fertilization, but the plot does not offer any broader reflections on the issue. Another topic that appears repeatedly in the series concerns temptations related to consumer culture; in the episodes young people often steal in order to get the money they need to buy name brand clothing and fashionable gadgets. In a conversation with the father of a young girl who had stolen something, Fr. Matthew tells the father to speak with his daughter about what the most important things in life are. The main statement that Fr. Matthew makes in many episodes is: "One should trust God and people." 26

\section{You Shall Not Steal}

The ordinary and seemingly calm residents of Sandomierz commit the thefts in the series Ojciec Mateusz. The motives for stealing are as difficult as the things stolen, which can be both material and immaterial goods. Often the stolen items are valuables taken from the homes of the wealthy residents of Sandomierz. Although, some episodes involve items such as an archeological find, cows, a valuable icon, a portable safe with money, or money from the poor box at church. Intangible goods are also stolen such as, for example, an idea for a crime story.

Sometimes the thieves commit petty theft for different reasons. A school janitor steals, claiming that she does not make enough to live.

\footnotetext{
$24 \quad$ Ojciec Mateusz, season 11, episode 143, "Gorące rytmy."

25 Ojciec Mateusz, season 11, episode 145, "Kurtka."

26 Ibid.
} 
Fr. Matthew usually listens to these individuals and, when possible, gives them the opportunity to correct their mistakes or admit their guilt and incur the appropriate punishment. In the series, theft also serves as an exciting adventure. In one episode, the main characters-three retired women - start a "gang" and steal items from stores just for the thrill of it. When talking to the three thieves, Fr. Matthew tries to help them understand how their behavior is immoral. He also does not report the case to the police and offers the culprits financial support to pay the stores for the items that they stole. In addition, he gives the women the opportunity to correct their mistakes and make up for their faults by working for a charitable foundation that helps those in need. ${ }^{27}$

In many episodes, the sixth commandment-You shalt not steal-is violated due to a consumerist lifestyle. The protagonists of these episodes are constantly seeking new sensations and pleasures and are ready to transgress the commandments and violate moral norms to achieve them. These scenes depict what can be called the subjectivization of morality. According to Flora Michaels, in the economics of the monoculture in which we live, economic efficiency and individual happiness, even at the expense of others, is what matters most. ${ }^{28}$ Consumerism disrupts value systems; "to have" takes precedence over "to be," even for believers, who are ready to violate God's commandments in the name of such a worldview. One example of this can be found in an episode where the protagonist_-a young man named Rafał—steals in order to get money to buy luxury items that his parents cannot afford. He, along with two other young criminals, robs a truck and takes goods from it that actually belong to other bandits. The robbed smugglers take Rafał's younger brother hostage; Rafał decides to rescue him and goes to Fr. Matthew for help. Rafał regrets confesses what he has done during his conversation with Fr. Matthew in the church. ${ }^{29}$ Fr. Matthew does not instruct Rafał, but he helps him. Fr. Matthew continues to encounter criminals, but he does not stigmatize them. Instead, he follows the philosophy that every encounter with another person is an encounter with God. He tries to show God in interpersonal relationships, in daily life. Through his daily tasks, such as sitting beside the sickbed of someone in the hospital, Fr. Matthew brings the viewers closer to God's Love, which is part of every person's life. ${ }^{30}$

\footnotetext{
27 Ojciec Mateusz, season 16, episode 205, "Gang."

28 F. Michaels, Monoculture: How One Story is Changing Everything (San Diego: Red Clover Press, 2011).
} 


\section{You Shall Not Bear False Witness Against Your Neighbor}

In the series Ojciec Mateusz, priests also commit crimes. Fr. Matthew's friend, Fr. Antoni Waluś, is an alcoholic who causes a car accident while drunk, injures a woman, and then attempts to hide it. In the end, however, through the persuasion of a friend, an old priest and his spiritual guide, Fr. Antoni Waluś admits his guilt. Throughout the series, criminals who confess what they have done (or who Fr. Matthew persuades to do so) often say moral maxims. At the end of the episode, the aforementioned alcoholic priest states: "There is guilt, so there must be punishment." 31 Bearing false witness against one's neighbor also occurs in another episode where a phony priest, who arrives to Fr. Matthew's rectory on a motorcycle, says to Fr. Matthew that he wants "to serve God and help those in need." ${ }^{2}$ The "priest" then joins in raising funds for the parish's charitable activities and then proceeds to steal the money and commit fraud. The man, however, is found out and arrested.

The other commandments against, for example, adultery, coveting one's neighbor's wife or things, are rarely featured in the other episodes of Ojciec Mateusz.

\section{Conclusion}

In Ojciec Mateusz, one can see the Decalogue mediated and shown through a pop-culture television series. Each episode revolves around a crime that Fr. Matthew and the viewers solve. In the background of the storyline lies a religious message about following Christian moral principles. The series is not a story in which a priest engages in theological discourse and directly draws the viewers to a transcendent realm. In the series and according to the conventions of the genre, the viewers do not watch the protagonists' moral dilemmas because the characters' psychology is depicted only superficially. The viewers can only guess when, for example, the camera shows Fr. Matthew praying or, more often, playing chess. At the same time, the way in which Fr. Matthew is depicted is faithful to the way in which consecrated persons live and serve God and others. Fr. Matthew's actions are quintessential of the axiology of Christian social life, which focuses on charity and responsibility for others in accordance with the tenet to conquer

\footnotetext{
$31 \quad$ Ojciec Mateusz, season 11, episode 141, "Wypadek."

32 Ojciec Mateusz, season 14, episode 184, "Sekretny układ."
} 
evil with good..$^{33}$ In the series, Fr. Matthew is a tool by which moral principles are formed, and he also gives witness to these principles in how he lives. To the viewer, it is important that Fr. Matthew is a modest man who does not consider material goods important (he does not even own a car). This attitude and example are particularly important due to the rapid secularization of Polish society and the proliferation of religious and moral indifference. ${ }^{34}$ In this way, Fr. Matthew is an emissary of the Church as a cultural institution, which plays a very positive role within society and supports all that is good and noble that arises from human charity, Her great "apostle."

A pop-cultural adaptation of a Polish priest may evoke religious feelings in Ojciec Mateusz's viewers. The series is a kind of morality play, since the good prevails and evil is punished in every episode. In the world that the series presents, unlike in real social life, there is a clear distinction between good and evil. The characters' actions, which often violate the Ten Commandments and are the natural consequence of the choices that they make, can be judged morally. However, the extent to which the series is perceived as a religious statement depends to a large degree on the viewers' attitudes toward religion. ${ }^{35}$ "The religious viewer moves [...] within an interpretive universe that is determined by a specific narrative, a set of narratives, or a range of social (religious) practices." ${ }^{36}$ For the believer who watches Ojciec Mateusz, the series can be a source of reflection on Christian moral norms, while for the unbeliever, it can be an opportunity to hear weekly about a good and gracious God and, without too much didacticism, simple moral guidelines by which to live."

\section{Bibliography}

1. Harrelson, W. "Dziesięcioro Przykazań.” In Stownik wiedzy biblijnej, edited by Metzger and M. Coogan, 135-136. Warszawa: 1996.

$33 \quad$ J.Zabielski, “Biblijna aksjologia życia społecznego chrześcijan,”Rocznik Teologii Katolickiej 10 (2011): 93.

34 J. Zabielski, "Degradacja życia religijno-moralnego jako zagrożenie ładu społeczno-cywilizacyjnego,” Rocznik Teologii Katolickiej 17, no. 3 (2018): 346.

35 M. Kempna, "Religijność jako paratekst. Na obrzeżach teorii filmu religijnego," in Pogranicza audiowizualności. Parateksty kina, telewizji i nowych mediów, ed. A. Gwóźdź (Kraków: 2010), 253.

36 C. Marsch, "Audience Reception," in The Routledge Companion to Religion and Film, ed. J. Lyde (London-New York 2009), 267, cited in M. Kempna, "Religijność jako paratekst," 254. 
2. Kempna, M. "Religijność jako paratekst. Na obrzeżach teorii filmu religijnego." In Pogranicza audiowizualności. Parateksty kina, telewizji i nowych mediów, edited by A. Gwóźdź. Kraków: Universitas, 2010.

3. Kłys, T. "Filmy (nie)religijne." In Między słowem a obrazem, edited by M. Jakubowska, T. Kłys, and B. Stolarska. Kraków: 2005.

4. Kraska, A. Wymiar transcendencji Dekalogu Krzysztofa Kieślowskiego wobec dylematów wspótczesnego człowieka. Doctoral dissertation, Adam Mickiewicz University, 2017. Accessed May 1, 2020. https://repozytorium. amu.edu.pl/handle/10593/20687.

5. Marczak, M. "Postać filmowa jako nośnik religijnego znaczenia. Ekranowe obrazy osób konsekrowanych w polskim kinie i telewizji od 2000 roku w funkcji socjokulturowego przekazu na temat współczesnej religijności." Media - Kultura - Komunikacja Społeczna 2, no. 12 (2016).

6. Marsch, C. "Audience Reception." In The Routledge Companion to Religion and Film, edited by J. Lyde, 267. London-New York: 2009.

7. Michaels, F. Monoculture. How One Story is Changing Everything. San Diego: Red Clover Press, 2011.

8. Rienecker, F., and G. Maier, eds. Leksykon biblijny. Translated by D. Irmińska. Warszawa: 2008.

9. Wichrowicz, O. C. J. Zarys teologii moralnej w ujęciu tomistycznym. Warszawa: 2016.

10. Zabielski, J. "Biblijna aksjologia życia społecznego chrześcijan.” Rocznik Teologii Katolickiej 10 (2011).

11. Zabielski, J. "Degradacja życia religijno-moralnego jako zagrożenie ładu społeczno-cywilizacyjnego.” Rocznik Teologii Katolickiej 17, no. 3 (2018). 